\title{
Can firms' market performance be explained better? Role of Strategy, Sustainability levers
}

\author{
John Ben P, Subramaniam D
}

\begin{abstract}
Practitioners of strategy such as $C$-suite executives as well as academicians have always expressed a keen interest in understanding the motivations for firm growth. Though they look at it from different dimensions, both confidently observe the impact of several strategy levers such as organic growth focus, the soft power focus exemplified by Michael Porter's 'bargaining power of the buyer', and the tangible resource focus that stems from investment in competence generating assets on the market performance of firms. Michael Porter also provided critical insights using an industry based perspective wherein he studied the levers of competitive advantage. Research studies have also incorporated the relevance of the industry environment and the role of different stakeholders in the overall progress of a firm. Theories such as the Resource Based View (RBV) as well as frameworks such as VRIO (Valuable, Rare, difficult to Imitate, Organized to capture value) have found acceptance among the practitioners since they have observed its power to explain the rationale behind firm growth and market performance. However, the sustainability and environmental focus has shot into prominence in the recent two decades on account of scholars such as John Wilkington. Hence, we find that strategy papers have now attempted to include an understanding of practices in this domain of sustainability and its corresponding impact (if any) on firm performance. At the same time, we also observe that research that delves into the cross linkages between the $R B V$ and the triple bottom line exemplified by the 3Ps (People, Planet and Profits) are relatively lesser in number. Hence, our paper aims to understand the linkages between the sustainability dimension as espoused by corporates as well as other strategy dimensions and firm performance.
\end{abstract}

Using the database PROWESS, managed by the Centre for Monitoring the Indian Economy, (CMIE), the study uses a sample of more than 500 companies and key findings indicate that there is a significant explanatory power of some strategy levers and the sustainability dimensions in unravelling the deeper reasons behind firm performance.

We use specific multivariate analysis techniques to support our findings. We observe that our paper contributes significantly to advancing a new framework to explain the firm performance; this has critical ramifications for academicians as well as practitioners of strategy - it has the potential to chart out newer growth trajectory for firms in an ultra-competitive business environment.

Index Terms: strategy levers, sustainability, firm performance, resource-based view

\section{INTRODUCTION}

In a very competitive environment, firms are keen to leverage their competencies consistently over longer time horizons. With a view to execution of strategies that lead to sustained

Revised Manuscript Received on August 25, 2019.

Dr. John Ben P*, Assistant Professor, Symbiosis Institute of Business Management, Bangalore, A constituent of Symbiosis International (Deemed University), E-mail: princejohnben@gmail.com

Dr. Subramaniam D, Adjunct Faculty, Symbiosis Institute of Business Management, Bangalore, A constituent of Symbiosis International (Deemed University), E-mail: subramaniam.d@sibm.edu.in competitive advantage, C-suite executives are constantly looking for newer forms of leverage [1] whereby resources intrinsic to the firm are used judiciously. Earlier, firms focused on building their infrastructure by way of dedicated fixed assets; these actions were often a way of Signaling strategic intent to their competitors [2]. Subsequently with gradual removal of global trade barriers, firms could now establish their supremacy on a global scale. This led to a deeper search for levers that could enable firms to not just compete successfully but also create stronger perception in the marketplace. Hence, we observe that organizations are now directing their efforts to rewarding investors over longer time frames. This brings into focus market-oriented performance of firms. Our paper seeks to identify those levers that transcend mere resource based advantage and utilize a host of other levers such as the sustainability focus and observe their impact on firms' market performance.

From a practitioner standpoint, the Top Management Teams (TMT) cannot afford to stay complacent even in scenarios where their organizations are in seemingly dominant positions. Cautionary tales are evident from the fall of giants such as Nokia, Kodak and Polaroid. The business landscape is littered with the silent remnants of such powerful and large organizations who once dominated their industries. Hence, firms are more keen to understand how competitive advantage can be sustained in industries of varying clockspeed [3]. Our paper seeks to unravel key levers that go beyond mere resource based interpretations of firms' performance. Here, our research picks up important cues from earlier scholars, identifies key gaps wherein work has been somewhat limited in nature and proceeds to empirically assess the significance of going beyond established theories such as the VRIO framework [4], include the sustainability levers and their contribution to market performance of firms.

\section{LITERATURE REVIEW}

Early proponents of strategy looked at the firm as a bundle of competencies $[5,6]$ embedded in a mixture of organizational structure [7,8] rent generating assets staffed with the right talent and leadership to drive competitive advantage [9,10,11].

Scholars who looked at tangible assets proposed ideologies which linked the possession of a set of resources $[12,13]$ as being integral to firm performance. The overarching themes were broadly pointing to the intricate mix of tangible and intangible assets [14] residing within the boundaries of the firm. 
Consequently, frameworks such as the VRIO proposed received widespread acceptance across the academic and practitioner environment on account of its explanation potential. Practitioners observed the validity of such frameworks since much of the organization's performance and basis for competitive advantage could be explained using such frameworks. Besides researchers also noted the strands of thought emerging from active criticisms of the theory $[15,16]$ and this led to further strengthening of the field of inquiry directed at the market performance of firms. Closely intertwined, yet accounting for the changing nature of the business environment, incrementally advanced theories such as the dynamic capabilities $[17,18,19]$ sought to explain the dexterity of firms which helped enhance their capabilities in alignment with the demands of the external environment.

Whilst firms continued to compete in ultra-competitive environments, the very fragile nature of the eco-system $[20,21]$ demanded more attention to itself. This in turn led to several scholars calling for responsible organizations. Organizations were now called upon to be model corporate citizens [22]. In doing so, the field of sustainability gained prominence. Since investors were always looking for newer approaches taken by firms, a reassurance that firms were taking concrete measures to address concerns of sustainability began a virtuous cycle [23]: organizations continued to incorporate sustainable practices. Such practices were also extended across their entire network of stakeholders [24,25] and became woven into the fabric of the strong interdependencies that existed across the supply chain. Our study incorporates the sustainability dimension as an important strategic lever; a clear influence can be seen on the investors' perceptions of firms.

Historically, academicians and industry stalwarts have assessed firm performance on two fronts - 1) accounting based measures of profitability and 2) market driven measures of profitability. While the first is clear and is not influenced by investors and shareholder perceptions, the second measure holds a lot of interest for scholars. Scholars have observed the effect of organizational orientations [26], the interplay between economic and organization specific factors [27], industry-specific versus firm specific influences [28,29], competitive strategies and their influence $[30,31]$ as well as choice of generic strategies [32] on market performance of firms. Research in this domain has often transcended industry boundaries, attempted to study the role of leadership, country specific factors and several other non-organization oriented dimensions. Results, however are not conclusive. Hence the field of inquiry that seeks to decipher the rationale for firms' performance has been an on-going perennially busy activity zone in the hallowed portals of eminent universities. Our research offers a different perspective in the sense that a host of factors are studied together: resource based views as well as sustainability focus are assessed for their influence on firm performance.

\section{DEVELOPMENT OF HYPOTHESES}

Conceptually, studies - both empirical and practitioner based have firmly established the predominance of the resource based theory and its explanatory powers. The evidence has been brought out through practitioner studies which have been tested across industries. Researchers have utilized several dimensions to understand the resource based theory. Studies have put forth a wide range of parameters and analyzed them to understand drivers of firm performance [33]. In parallel, these studies have also attempted to understand the softer, fine-grained competencies gained such as tacit knowledge, capabilities and have included organizational structure specific strategic routines such as business processes [34] in their quest to untangle the antecedents of firm performance. Delving deeper into how firms take a long term view, we find firms that are confident of long term sustained performance take up expansion initiatives on a war footing. Hence the expansion intent is often signalling to the market, through addition of firm specific assets. At the same time, organizations commit substantial proportion of their sales revenue to long term strategic orientation by way of acquiring tangible machinery, plant or equipment. Hence, this leads us to the hypothesis:

\section{H1: Strategic lever of resource based expansion has a positive and significant influence on performance of firms}

A producer centric era meant that firms could progress as stakeholders had little or no say in the means of achieving profitability. The era saw that large firms dominated the industrial landscape [35] - for instance, Ford, General Electric and others. However, with the advent of Japanese competitors, American and European giants came up short: their organizational flab and inertia was exposed, making them vulnerable to competitive exploits, thereby weakening their positional strength. Hence, one of the first initiatives was to cut down on this flab by virtue of investing in a host of organizational initiatives such as the Total Quality Management, Lean management among others. Yet, organizations were unable to make much headway in the face of stiff competition from the Asian upstarts, which had subsequently metamorphosed into conglomerates within two decades. In the recent century, attention was directed towards stakeholders and the business environment, thereby leading to triple bottom line [36]. A more transparent form emerged over the years which was manifested in the form of corporate social responsibility [37], sustainable business processes amidst a host of approaches aimed at appeasing the environmentalists. Academic research in this domain started studies to measure the impact of these initiatives on the market performance of firms and found mixed results. Hence, this leads us to framing, tentatively, the hypothesis,

\section{H2: Strategic lever of sustainability focus has a positive and significant influence on performance of firms}

An outward oriented view taken up by organizations can be manifested in the form of measures that are aimed at society and the community. However, it may also be evident in the sustainable practices [38] that are built into the firms' routines [39] over the organizational supply chain. 
Investors and others who wish to take pride and share of profit in the firms' performance, however do not necessarily attribute the sustainability dimension to financial or market performance. Across the world, as activists call for attention, exhorting investors to probe deeper, understand whether behemoth corporations have really adopted sustainable practices in their supplier organizations, the conglomerates in turn have taken adequate measures (for instance, Apple Inc., Nike), extending their far flung resources across continents, enforcing stringent norms and punitive action on their tier 1, tier 2 and leading upto tier $\mathrm{n}$ ( $\mathrm{n}$ may be as large as 10) suppliers. However, our concern is also about whether there have been consistent efforts to maintain sustainable business processes across all the stakeholders of the firm. This leads us to frame the hypotheses.

H3: The consistency of commitment to sustainability

focus has a positive and significant influence on performance of firms

While resource based theorists such as Wernerfelt and Jay Barney have empirically tested various related models and theories in this domain, an organizational risk taking orientation may stem from innate legacies as well as top management teams' orientation. Studies which tested the effect of age and legacy factors on firm performance [40] also analyzed the founder-centric characteristics and its impact on evolution of these firms. On the contrary, [41] observed the effects of learning orientation on performance. In a bid to increase the resource base, risky positions are often taken up by some organizations; for instance, Suzlon, an Indian firm which used a debt-financing strategy to acquire REpower (the European energy giant) - however, in this case, Suzlon recently reported accumulated debt of $\$ 2$ billion and inability to repay. Yet, an ambitious organization with a strong and optimistic outlook is likely to take recourse to debt-led expansion. Extending the same line of thinking, but with more focus directed towards how firms' signal their intentions [42], a growth strategy is often portrayed by way of visible signs $[43,44]$ whereby firms spend on a host of marketing and advertising activities that are aimed at sending out signals to their competitors. [45] developed a unique approach to represent corporate aggressiveness wherein risk-taking stance of firms and market signalling were considered very strongly. Hence, this leads us to the hypothesis

\section{DATA AND METHODS}

\section{A. Dependent Variable}

The study calls for usage of a suitable representative variable for market performance of firms. Recent literature has strongly endorsed the use of Price to Book value, as an appropriate value. This reflects the views of investors in the firms; also most of the stock markets use this as a barometer of the firms' performance. In addition, there are other ratios such as price-to-earning multiple, dividend pay-out ratio which also signal the competitive market oriented nature of firms. For our study, we utilize the Price to Book value, taken at end

\section{H4: The signalling intensity of firms in the marketplace has a significant influence on firms' market performance}

of March 2017, in our study as representative of firms' market performance

\section{B. Independent Variables}

To understand resource based expansion, we utilize the firms' tendency to indicate organic growth strategy - this in turn is represented through addition of resources in the form of fixed assets. This may be a mixture of machinery, capital equipment besides other related tangible forms of investments. Our representative or proxy here is the Assent Intensity (ASSETINT) which is computed as the ratio of the last three years' total investments in fixed assets to the total sales for the firm during the same time period.

Sustainability focus is evident when firms spend on a blend of strategic activities that are aimed at reducing pollution, carrying out social and community expenditure and engaging in practices that show concern for sustainable business processes. To compute this variable, Sustainability Intent (SUST_INT), we have used a ratio of the sum of spends on these heads for the previous three years to the firm's profit after tax during the same time period. Consistency of sustainability is equally important; several firms spend on such initiatives for shorter time periods, following which there is a lull or lack of noticeable spends. Hence, the Consistency of Sustainability Intent (CONSIS_SUS_INT) captures this behaviour of firms which is a nominal variable taking the value of 1 if firms have spent consistently during the three years leading to Year 2017 and 0, otherwise. Competitive Signalling Intent (COMPET_SIG_INT) is represented as the sum of expenditure over the last three years on marketing and advertising activities to the sum of sales during the same time period

\section{TABLE 1: Univariate Statistics}

\begin{tabular}{|c|c|c|c|c|c|c|c|c|c|c|}
\hline VARIABLES & Mean & $\begin{array}{l}\text { Standard } \\
\text { Deviation } \\
\end{array}$ & (1) & (2) & (3) & (4) & (5) & (6) & $(7)$ & (8) \\
\hline (1) $P_{-}$BOOKVAL & 4.37 & 6.59 & 1.00 & -0.02 & -0.08 & 0.23 & 0.02 & -0.02 & -0.02 & 0.06 \\
\hline (2) ASSETINT & 0.14 & 20.06 & & 1.00 & 0.02 & -0.01 & 0.04 & 0.06 & 0.01 & 0.03 \\
\hline (3) SUST_INT & 0.02 & 0.03 & & & 1.00 & 0.03 & 0.14 & 0.06 & 0.09 & 0.16 \\
\hline (4) COMPET_SIG_INT & 0.02 & 0.03 & & & & 1.00 & 0.02 & -0.05 & 0.10 & 0.10 \\
\hline (5) CONSIS_SUST_INT & 0.55 & 0.50 & & & & & 1.00 & 0.05 & 0.02 & 0.16 \\
\hline (6) SIZE & 76865 & 269823 & & & & & & 1.00 & 0.09 & 0.04 \\
\hline (7) $\mathrm{AGE}$ & 39.29 & 22.05 & & & & & & & 1.00 & 0.12 \\
\hline (8) PAT_SALESRATIO & 0.04 & 0.17 & & & & & & & & 1.00 \\
\hline
\end{tabular}

TABLE 2: Regression Output

\begin{tabular}{lccccc} 
& $\begin{array}{c}\text { Unstandardized } \\
\text { Coefficients }\end{array}$ & $\begin{array}{c}\text { Std. } \\
\text { Error }\end{array}$ & Beta & $\mathrm{t}$ & Sig. \\
\hline (Constant) & 3.93 & 0.62 & & 6.34 & 0.00 \\
ASSETINT & -0.01 & 0.01 & -0.02 & -0.48 & 0.63 \\
SUST_INT** & 23.90 & 10.63 & 0.09 & 2.25 & 0.02 \\
COMPET_SIG_INT*** & 49.93 & 8.62 & 0.23 & 5.79 & 0.00 \\
CONSIS_SUST_INT & 0.33 & 0.53 & 0.02 & 0.62 & 0.54 \\
SIZE & 0.00 & 0.00 & 0.00 & -0.08 & 0.93 \\
AGE & -0.01 & 0.01 & -0.04 & -1.04 & 0.30 \\
PAT_SALESRATIO & 2.06 & 1.60 & 0.05 & 1.29 & 0.20 \\
\hline
\end{tabular}




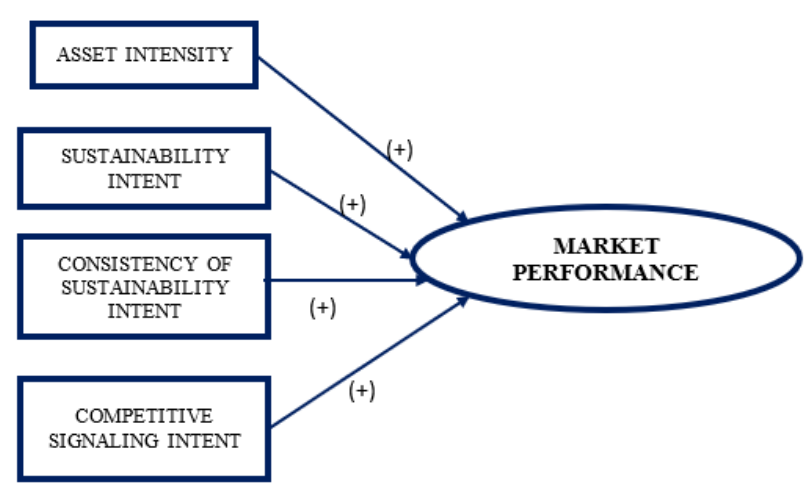

FIGURE 1: Conceptual Framework

\section{Sample and Control Variables}

Using the database PROWESS, managed by Centre for Managing the Indian Economy, (CMIE), we take the complete set of firms that are listed on the Bombay Stock Exchange. Removing firms that are less than INR 10000 Crores (equivalent to US $\$ 1.5$ billion, considering $\$ 1=$ INR 68 ) in turnover as well as eliminating firms that did not report sales for the year 2017, we arrive at a sample of 607 firms, which forms the basis of our study. Age of firms and Sales of firms for the year 2017 have been taken as control variables. The conceptual diagram is represented in Figure 1.

We use Ordinary Least Squares OLS regression to assess the relationship between the various constructs in our study and firm performance. Univariate statistics (Table 1) are tabulated.

The results of OLS regression have been tabulated. The $\mathrm{F}$ value is found to be 5.97 and significant at the $1 \%$ level. The explanatory power variable, $\mathrm{R}^{2}$ however, is relatively weak. Hence we may infer that only about $6 \%$ of the variation in the market performance (price to book value) is explained by the strategy variables. Surprisingly, even the control variables do not seem to have contributed much to explaining why the variation in firms' market performance exists. The results have been tabulated.

\section{DISCUSSION OF FINDINGS}

The study has thrown up some interesting results. Table 2 gives the regression output. Firstly, we find that the competitive signalling intent has been found to significantly explain firm performance: hypothesis $\mathrm{H} 4$ is supported. While this has reinforced the view of organizations, from a research standpoint, it endorses several earlier studies (For instance, studies by Fombrun and Ginsberg) who were the earliest to develop the representative measure. [46] also observed a positive impact of advertising intensity on firm performance, even while their study focused on research and development intensity as well.

Secondly, we observe that the investors possibly ascribe more importance to the spends on sustainability initiatives. This may be interpreted thus: markets value the sensitivity that firms have portrayed by way of various initiatives targeting sustainable business processes or operations, the observation also substantiated by hypothesis $\mathrm{H} 2$ being supported. Our study has shown one encouraging result; the coefficient is positive and shows a strong positive influence on the market performance.
However, the other variables where expectations based on literature review and logical relationship showed a surprising lack of significant impact on firm performance. Our paper notes that hypothesis $\mathrm{H} 1$ and $\mathrm{H} 3$ are not supported. Here, the coefficients were also of smaller magnitude and display no influence on the market performance of organizations. Several reasons could be advanced: firstly, asset intensity of firms have been found to be varying - some firms have been reducing their net fixed assets, possibly on account of re-structuring or divestments. Another possibility is that firms are moving towards greater focus on services. Another area where no significant result was noticed pertains to consistency of sustainability - here results show no significance, indicating that the market does not perceive any differential or significant value.

\section{CONCLUSIONS AND FUTURE RESEARCH DIRECTIONS}

While the study sought to understand some of the strategy levers in terms of their ability to influence firm performance, several useful insights have emerged. Firstly, we are quite clear that markets are likely to reward those firms that have exhibited greater interest in sustainable business processes and operations. This has been proved by our statistical results wherein $\mathrm{p}<0.05$ and by the magnitude of the relevant coefficient. For firms it implies a greater need to sustain their efforts - a greater emphasis on usage of material, design of business processes and disposal mechanisms for various products would be beneficial for firms in the long run. Considering that the earlier years between 2012 to 2015 saw little evidence of spends on sustainability, the results are encouraging and likely to nudge organizations to maintain consistent efforts.

Secondly, the competitive signalling by way of a host of activities - both tactical and strategic have reinforced the belief of firms in sustaining their market efforts. This implies that firms would need to maintain their standing by spending more on a wide range of market-reach activities: predominantly spends on media, advertising, promotional activities. Statistically, the p-value being less than 0.01 , the results are more encouraging; this calls for further study, whereby robustness tests could be employed and the cross sectional study could be taken up in different years. Alternatively, panel data regressions could be carried out across time span of 10 to 15 years, thereby capturing the effect of overall macroeconomic conditions and their influence on firms, as well.

Finally, areas where the study found lack of results also need to be discussed: for instance, investors and markets are not really concerned about the legacy factors such as age or size of firms. Older firms do not seem to be regarded more highly by investors. Similarly, tangible assets no longer seem to find favour with investors in terms of market performance; this could be on account of a host of service related or value offered by the firms' products. 
Momentum seems to be shifting towards to the overall bouquet of services and value add that satisfy customers both retail and institutional. Future researchers may find greater meaning in delving deeper into the value provided by firms - both tangible and intangible. To this end, there are clear exhortations from investors calling for meaningful actions by firms - both operational and strategic; significant efforts would have to be directed towards sustainable organizational activities in future.

\section{REFERENCES}

1. G.L. Neilson, K.L. Martin, and E. Powers, "The secrets to successful 81-94. 2008

2. G.C. Hamel and C.K. Prahalad, "Strategic Intent," Harvard Business Review, vol. 63, no. 4, pp. 148-161, 1989

3. C.H. Fine, Clockspeed: Winning industry control in the age of temporary advantage, Harper Collins, 1998

4. J.B. Barney, "Firm resources and sustained competitive advantage," Journal of Management, vol. 17, no. 1, pp. 99-120, 1991.

5. D.M. De Carolis, "Competencies and imitability in the pharmaceutical Journal of management, vol. 29, no. 1, pp.27-50, 2003.

6. H. Scarbrough,) "Path(ological) dependency? Core competencies from an organizational perspective," British journal of management, vol. 9 , no. 3, pp.219-232, 1998.

7. R.E. Miles, C.C. Snow, A.D. Meyer and H.J. Coleman Jr, "Organizational strategy, structure, and process," Academy of management review, vol. 3, no. 3, pp.546-562, 1978

8. W. Zheng, B. Yang and G.N. McLean, "Linking organizational culture, structure, strategy, and organizational effectiveness: Mediating role of knowledge management," Journal of Business research, vol. 63, no. 7, pp.763-771, 2010.

9. I. Dierickx and K. Cool, "Asset stock accumulation and sustainability of competitive advantage," Management science, vol. 35, no. 12, pp.

10. M.A. Peteraf, "The cornerstones of competitive advantage: a resource-based view," Strategic management journal, vol. 14, no. 3, pp.179-191, 1993.

11. J.H. Dyer, H. Singh, H. W.S. Hesterly, "The relational view revisited: A dynamic perspective on value creation and value capture," Strategic Management Journal, vol. 39, no. 12, pp.3140-3162, 2018

12. B. Wernerfelt, "A Resource-based View of the Firm," Strategic Management Journal, vol. 5 no. 2, pp. 171-180, 1984.

13. J.B. Barney, M. Wright and D.J. Ketchen Jr., "The resource-based view of the firm: Ten years after 1991," Journal of management, vol. 27, no. 6, pp.625-641, 1991.

14. J.B.Barney. Gaining and Sustaining Competitive Advantage. Addison-Wesley: Reading, MA, 1997.

15. T. El Shafeey and P. Trott "Resource-based competition: three schools of thought and thirteen criticisms," European Business Review, vol. 26, no. 2, pp.122-148, 2014.

16. A. Enders, A. König, H. Hungenberg and T. Engelbertz, "Towards an integrated perspective of strategy: The value-process framework," Journal of Strategy and Management, vol. 2, no. 1, pp.76-96, 2009.

17. Teece, D.J., Pisano, G. and Shuen, A. (1997) 'Dynamic capabilities and strategic management', Strategic management journal, Vol. 18, No. 7, pp.509-533.

18. K.M. Eisenhardt, and J.A. Martin, "Dynamic capabilities: what are they," Strategic Management Journal, vol. 21, no. 10-11, pp.1105-1121, 2000.

19. D.J. Teece, "Business models and dynamic capabilities," Long Range Planning, vol. 51 no. 1, pp. 40-49, 2018.

20. C. Nilsson and G. Grelsson, "The fragility of ecosystems: a review," Journal of Applied Ecology, pp. 677-692, 1995

21. P.F. Drucker, "The new society of Organizations," Harvard business review, vol. 20, no. 5, pp.281-293, 1992.

22. A.B. Carroll, "Corporate social responsibility: Evolution of a definitional construct," Business \& society, Vol. 38, No. 3, pp.268-295, 1999.

23. L. Newman, "The virtuous cycle: incremental changes and a vol. 15 , no. 4, pp.267-274, 2007. strategy execution," Harvard business review, vol. 86, no. 6, pp. industry: An analysis of their relationship with firm performance," 1504-1511, 1989. process-based sustainable development," Sustainable development.

24. H.M. Haugh and A. Talwar, "How do corporations embed sustainability across the organization?," Academy of Management learning \& education, vol. 9, no. 3, pp.384-396, 2010.

25. D. Crilly, M. Hansen and M. Zollo, "The grammar of decoupling: A cognitive-linguistic perspective on firms' sustainability claims and stakeholders' interpretation," Academy of Management Journal, vol. 59, no. 2, pp.705-729, 2016.

26. S.C. Lonial and R.E. Carter, "The impact of organizational orientations on medium and small firm performance: A resource-based perspective," Journal of Small Business Management, vol. 53, no. 1, pp. 94-113, 2015

27. G.S. Hansen and B. Wernerfelt, "Determinants of firm performance: The relative importance of economic and organizational factors," Strategic management journal, vol. 10, no. 5, pp.399-411, 1989

28. G. Hawawini, V. Subramanian and P. Verdin, "Is performance driven by industry-or firm-specific factors? A new look at the evidence," Strategic management journal, vol. 24, no. 1, pp.1-16, 2003.

29. L. Larry S.Z. Islam, "Firm and industry specific determinants of capital structure: Evidence from the Australian market," International Review of Economics \& Finance, vol. 59, pp. 425-437, 2019.

30. M.J.R. Ortega, "Competitive strategies and firm performance: Technological capabilities' moderating roles," Journal of Business Research, vol. 63, no. 12, pp.1273-1281, 2010.

31. T. Lee, "Management ties and firm performance: Influence of family governance," Journal of Family Business Strategy, vol. 10, no. 2, pp 105-118, 2019.

32. G.G. Dess, and P.S. Davis, "Porter's (1980) generic strategies as determinants of strategic group membership and organizational performance," Academy of Management journal, vol. 27, no. 3, pp.467-488, 1984.

33. G. Ray, J.B. Barney, and W.A. Muhanna, "Capabilities, business processes, and competitive advantage: choosing the dependent variable in empirical tests of the resource-based view," Strategic management journal, vol. 25, no. 1, pp.23-37, 2004.

34. S.L. Newbert, "Empirical research on the resource-based view of the firm: an assessment and suggestions for future research," Strategic management journal, vol. 28, no. 2, pp.121-146, 2007.

35. A.D. Chandler, Strategy and structure: Chapters in the history of the industrial enterprise (Vol. 120). MIT press, 1990,

36. J. Elkington,), "Partnerships from cannibals with forks: The triple bottom line of 21 st-century business," Environmental quality management, vol. 8, no. 1, pp.37-51, 1998 .

37. M.E. Porter, and M.R. Kramer, "The link between competitive advantage and corporate social responsibility," Harvard business review, vol. 84, no. 12, pp.78-92, 2006.

38. F. Hofmann, "Circular business models: Business approach as driver or obstructer of sustainability transitions?," Journal of Cleaner Production, vol. 224, pp. 361-374, 2019.

39. R. Lubit, "The keys to sustainable competitive advantage," Organizational dynamics, vol. 29, no. 3, pp. 164-178, 2001.

40. R.C. Anderson and D.M. Reeb, "Founding-family ownership and firm performance: evidence from the S\&P 500," The Journal of Finance, vol. 58, no. 3, pp. 1301-1328, 2003.

41. R.J. Calantone, S.T. Cavusgil and Y. Zhao, "Learning orientation, firm innovation capability, and firm performance," Industrial marketing management, Vol. 31, No. 6, pp.515-524, 2002.

42. A. Kaleka, N.A. Morgan, "How marketing capabilities and current performance drive strategic intentions in international markets," Industrial Marketing Management, vol. 78, pp. 108-121, 2019.

43. P. Herbig and J. Milewicz, "Marketing signals in service industries: implications for strategic decision making and profitability," Journal of Services Marketing, vol. 8, no. 2, pp.19-35, 1994.

44. M.N. Hertzendorf and P.B. Overgaard, "Price competition and advertising signals: Signaling by competing senders," Journal of Economics \& Management Strategy, vol. 10, no. 4, pp. 621-662, 2001

45. C.J. Fombrun, and A. Ginsberg, "Shifting gears: Enabling change in corporate aggressiveness," Strategic Management Journal, vol. 11, no. 4, pp. 297-308, 1990.

46. T.L. Andras, and S.S. Srinivasan, "Advertising intensity and R\&D intensity: Differences across industries and their impact on firm's performance," International Journal of Business and Economics, vol 2, no. 2, pp. 81-90, 2003.

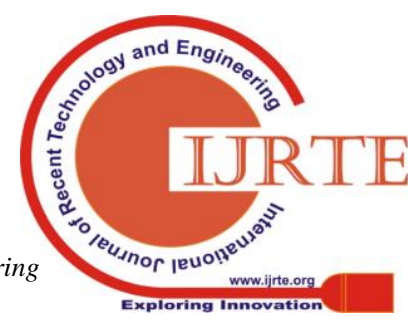




\section{AUTHORS PROFILE}

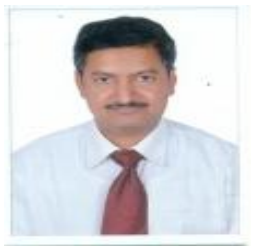

Dr. John Ben $\mathrm{P}$ is an Assistant Professor at Symbiosis Institute of Business Management, a constituent of Symbiosis International (Deemed) University. He has been teaching for the last seven years. Previously he worked in several organizations for about ten years. His work experience spans automobile industry and apparel retailing. In the automobile firm, he was mainly associated with lean initiatives and their implementation on the shop floor. At retailing firms, he was predominantly involved in various supply chain activities for brands. He teaches subjects such as operations management, total quality management and technology and innovation management. He has published papers in reputed journals and has attended international conferences.

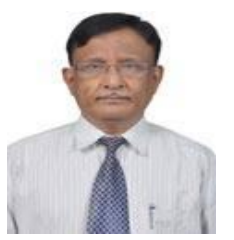

Dr. Subramaniam D is presently working as Adjunct faculty at Symbiosis Institute of Business Management, a constituent of Symbiosis International (Deemed) University. He has a rich blend of industry and teaching experience. He worked in the industry for over thirty years, where his areas of expertise were in materials and logistics function. He was instrumental in driving initiatives related to efficient vendor management, adoption of best practices in sourcing and was involved in a blend of operational and strategic roles. He has been teaching for the last ten years. He teaches subjects such as supply chain management, logistics management and strategic management. He has authored several papers in reputed journals and has presented papers in important conferences. 